\title{
Satisfaction with service recovery: Its measurement and its outcomes
}

\author{
C. Boshoff* \\ Department of Business Management, University of Port Elizabeth, \\ PO Box 1600, Port Elizabeth 6000, Republic of South Africa \\ ecahcb@upe.ac.za \\ G. Staude \\ Rhodes Investec Business School, Rhodes University, \\ Grahamstown 6140, Republic of South Africa
}

Received June 2003

\begin{abstract}
Persistent poor service delivery will have a harmful impact on the survival and growth prospects of service firms. The literature contends that, if service failures occur, there are strategies that service firms can employ to return customers to a state of satisfaction. Very little scholarly research has been done, however, to assess the satisfaction of customers after service firms have tried to recover from service failure. Although anecdotal evidence suggest it, no empirical research has been done to confirm that effective service recovery will ensure 'overall' satisfaction, or the long-term loyalty of complaining customers.
\end{abstract}

The purpose of this study is to assess the validity and reliability of an instrument purported to measure satisfaction with service recovery (RECOVSAT), and to determine which dimensions of service recovery satisfaction are the most important predictors of overall satisfaction and loyalty.

*To whom all correspondence should be addressed.

\section{Introduction}

The discipline of marketing is primarily based on the philosophy of the so-called 'marketing concept' (Perreault $\&$ McCarthy, 1996). If properly implemented, adherence to the marketing concept should lead to a firm-wide customer orientation which places the understanding of customer needs and wants at the centre of efforts to tailor product or service offerings, in order to satisfy those needs. Unfortunately, many firms fail to implement the marketing concept properly during their daily activities. Newspaper headlines such as 'Wrong foot amputated' and 'SAA apologises for leaving child on plane' are not uncommon. Poor service delivery, if allowed to continue, will threaten the long-term survival of the firm.

Although there are some that would disagree, service is generally regarded as a unique entity from a marketing perspective (Murray, 1991; Zeithaml, Parasuraman \& Berry, 1985). Service, the argument goes, is an intangible entity, and therefore needs a different and unique marketing approach when compared to marketing a physical product. Also, for a service to be 'produced', the customer must be present (Zeithaml et al., 1985). Because services are often produced in the presence of the customer during the socalled 'service encounter', service firms need to be particularly vigilant as service failures can often not be hidden from customers. The situation-specific and 'immediate' nature of service delivery and service failure calls for relatively speedy and effective attempts to recover from poor service delivery, in order to avoid the resultant harmful outcomes.

Unfortunately, few service firms have well-established service recovery strategies (Bitner, Booms \& Mohr, 1994) despite the fact that there is evidence that customers are more likely to stay loyal to a firm if they know that their complaint will be addressed against the background of established corporate policies (Bowen \& Lawler, 1992). This caveat may be attributable to the absence of a measuring instrument to objectively assess complaining customers' assessment of service recovery efforts. An instrument to achieve this was recently published. The 17item RECOVSAT instrument has been proposed to measure satisfaction with service recovery (Boshoff, 1999). The instrument has demonstrated excellent construct validity during its development. A psychometric assessment with actual complaining customers is, however, still lacking.

Against this background, the customers of a national bank who had actually lodged a complaint with the bank were surveyed. By using RECOVSAT, it was possible not only to objectively assess complaining customers' satisfaction with the bank's service recovery efforts, but also to assess the psychometric qualities of RECOVSAT.

\section{Service recovery and its outcomes}

Zemke and Bell (1990:43) define service recovery as a '...thought-out, planned process for returning aggrieved customers to a state of satisfaction with the firm after a 
service or product has failed to live up to expectations'. Service recovery thus refers to the actions of a service firm in response to a service failure. The objective is to maintain the business relationship with the customer (Schweikhart, Strasser \& Kennedy, 1993). This contention is based on the premise that customer satisfaction ensures customer loyalty, repeat sales, and positive word-of-mouth communication (Bearden \& Teel, 1983). Effective service recovery also leads to enhanced perceptions of the quality of products and services already bought, enhanced perceptions of the firm's competence, and a favourable image in terms of perceived quality and value (Kelley \& Davis, 1994; Zemke \& Bell, 1990: 43).

On the other hand, failure to ensure customer satisfaction through service recovery could lead to a decline in customer confidence, lost customers, negative word-of-mouth, possible negative publicity, and the direct cost of reperforming the service (Berry \& Parasuraman, 1991). In essence, the service firm's true test of commitment to service quality and customer satisfaction depends on how it responds after the disconfirmation of customer expectations (Zemke \& Bell, 1990), and frontline staff play a key role in this response.

Employee behaviour that causes disconfirmed expectations (as opposed to problems caused by faulty systems or policies) is one of the most difficult types of failure from which to recover (Hoffman, Kelley \& Rotalsky, 1995:59). Often customers switch to an alternative service provider, not because of core service failure, but because of the unacceptable response of employees to customer attempts to redress failure (Keaveney, 1995:77). The assessment of how successful a service recovery was, must thus focus on the response of service firm employees.

\section{The development of RECOVSAT}

A central theme in any consideration of service recovery is customer satisfaction. Service recovery must contribute to, and enhance, customer satisfaction. The development of the RECOVSAT instrument was primarily based on the Disconfirmation Paradigm (Smith \& Houston, 1983). The initial empirical work attempted to determine what consumers expected of service firms once a service failure had occurred and a complaint had been lodged. The idea was that, once service recovery had taken place, RECOVSAT would be used to assess satisfaction with the firm's service recovery effort. In other words, where, during the development phase the consumers were questioned about their expectations, in this study they were asked about their satisfaction with the actions of the recovering firm.

Following two large empirical surveys and the scale purification procedures recommended by Churchill (1979), the final RECOVSAT instrument measured six dimensions of satisfaction with service recovery, using 17-items linked to a Likert-type scale (Boshoff, 1999).

\section{The dimensions of service recovery satisfaction}

The developer of RECOVSAT (Boshoff, 1999) suggests that six dimensions make up the construct of service recovery satisfaction, and that customers' satisfaction with a firm's service recovery effort may have to be measured on these dimensions. The six dimensions are Atonement, Communication, Feedback, Empowerment, Tangibles, and Explanation.

\section{Atonement}

Equity theory suggests that people analyse the ratio of outcomes and inputs that they receive, relative to the ratio of outcomes and inputs of other parties in social exchanges. In other words, equity theory proposes that true equity is attained only when the ratio of outcomes to inputs is equal for all parties, and a customer will complain if the input/output equilibrium has been sufficiently disturbed (Oliver \& Swan, 1989:22-24). When there is a breakdown in service delivery, it may well be that customers expect to have their ratio of outcomes adjusted in order to compensate for the service failure (Sparks \& Callan, 1995). In this context, atonement refers to some value-added compensation to restore the ratio of inputs to outputs, by 'making it up to the customer' for the inconvenience of service failure.

\section{Communication}

When considering communication in a service recovery context, it can refer to the amount of communication, the timing of communication, the frequency of communication, and communication style. Communication style refers to the manner in which service employees address the customer lodging a complaint (Sparks \& Callan, 1995). These communication styles were of two types: 'convergence' and 'maintenance'. Convergence refers to a communication style in which the service provider uses a range of strategies to signal liking, helpfulness, similarity, or understanding. Vocally, verbally and non-verbally, the service provider becomes more like the customer during these communication behaviours. Maintenance style is similar to a standardised approach to a service. There is no effort to change or move toward the customer vocally, verbally or non-verbally

\section{Empathy}

'Empathy' is defined as caring, individualised attention that the firm provides to its customers (Zeithaml et al., 1990: 26). Empathy means treating the customer in a way that shows that the service provider cares about the problem, fixing the problem, and lessening the customer's inconvenience. Zeithaml et al. (1990: 26) found in the development of the service quality measuring instrument SERVQUAL, that employees of a service firm demonstrating empathy during a service encounter, can positively influence customer perceptions of a service firm. 


\section{Feedback}

'Feedback' refers to the situation in which, once the problem is solved, the service firm provides information about the problem and what is being done to resolve it. For example, if the customer lodges a complaint and the firm's procedures are changed in some way because of the customer's input, then the service firm should inform the customer of the developments.

\section{Empowering employees}

'Empowerment' is the authority to act, and refers to the resources to which employees have access, and the decisions they are permitted to make (Hart, Heskett \& Sasser, 1990:155). Hartline and Ferrell (1996:66) have shown that allowing frontline employees to use their own initiative and judgement, improves the quality of service they deliver to customers.

Training and empowering employees are, however, interdependent, because there is no point in training employees to solve problems if is not accompanied by the power to act on their own initiative and to fix a service failure in the way that they see fit. Therefore, it may not matter how friendly, pleasant or attentive an employee is to a customer, if he/she is not able to solve the problem or to be seen as trying to help. The customer will just become more dissatisfied with the service and the firm could lose a valuable customer.

\section{Tangibles}

The dimension 'tangibles' refers to the appearance/standard of dress of employees, the equipment they use, and the physical environment in which they handle complaints. Zeithaml et al's (1990:26) findings illustrated that tangibles are among the most important dimensions that customers use to evaluate service quality. Both the service industry executives and the focus group participants taking part in this study confirmed that tangibles play an important role in customers' assessment of service recovery satisfaction as well.

\section{Explanation}

Service employees often use an explanation to defend their reputation in the face of a complaint, and in an attempt to ensure that the customer remains loyal, despite the dissatisfaction (Conlon \& Murray 1996:1042). 'Explanation', for the purposes of this study, refers to whether the service provider explains to the customer why the problem occurred, in a clear and concise manner. It does not include an acknowledgement of responsibility or an apology. Sparks and Callan's (1995) findings suggest that the type of explanations given are salient factors used by customers in evaluating the service, and particularly service recovery efforts.

To summarise, RECOVSAT suggests that, to ensure a successful service recovery, a service firm should communicate effectively with the aggrieved customer, be empathetic, provide feedback, offer an explanation of what went wrong, empower employees who receive complaints to solve the problem that the customer complained about, and ensure that staff are appropriately dressed and appear professional in terms of the appearance of their working environment.

\section{Objectives}

The objectives of this study were two-fold. The first was to do a psychographic assessment of the RECOVSAT instrument by evaluating its discriminant validity, its predictive validity, and its reliability. A second objective was to assess the impact of individual service recovery dimensions on outcome variables such as 'Overall Satisfaction' and Loyalty.

Based on these objectives, the following propositions and hypotheses were considered:

Propositions

P1: RECOVSAT demonstrates sufficient discriminant validity.

P2: RECOVSAT demonstrates sufficient predictive validity

P3: RECOVSAT is a reliable instrument to measure satisfaction with service recovery

Hypotheses

$\mathrm{H} 0^{1}$ : There is no relationship between individual dimensions of service recovery and overall satisfaction

$\mathrm{H}^{2}$ : There is no relationship between individual dimensions of service recovery and loyalty

\section{Methodology}

\section{The sample}

A major South African bank participated in the study. Their database of customers who registered a complaint with the bank during the preceding six months constituted the population. The database of registered complaints thus also served as sampling frame. A stratified sampling procedure was used to ensure that a national sample covering all the major geographic regions of South Africa was covered. Individual names in each stratum were selected on a random basis according to the method of 'sampling without replacement' (Malholtra, 1999).

It was decided that a sample of 750 bank customers should be drawn to ensure adequate national coverage.

\section{Data collection}

Data was collected by means of telephonic interviews, using the RECOVSAT instrument. In total, 750 successful interviews were conducted. After the removal of questionnaires with missing data, 702 useable questionnaires could be analysed. 


\section{The empirical results}

\section{Descriptive analysis of the data}

Table 1 provides a demographic description of the realised sample. It shows that the sample is slightly skewed towards males who have been customers of the bank for more than ten years. The realised sample is, however, according to the bank, representative of the bank's customer profile.

Table 1: The demographic composition of the realised sample

\begin{tabular}{l|r|r}
\hline Years Customer & \multicolumn{1}{|c|}{$\mathbf{n}$} & $\mathbf{\%}$ \\
\hline $0-3$ years & 128 & 18,2 \\
\hline $4-6$ years & 89 & 12,7 \\
\hline $7-9$ years & 58 & 8,3 \\
\hline $10+$ years & 342 & 48,7 \\
\hline No response & 85 & 12,1 \\
\hline Total & $\mathbf{7 0 2}$ & $\mathbf{1 0 0 , 0}$ \\
\hline & & \\
\hline Gender & & 60,0 \\
\hline Male & 421 & 37,5 \\
\hline Female & 263 & 2,5 \\
\hline No response & 18 & $\mathbf{1 0 0 , 0}$ \\
\hline Total & $\mathbf{7 0 2}$ & \\
\hline Age & & ----- \\
\hline $0-20$ years & 2 & 9,6 \\
\hline $21-29$ years & 68 & 22,9 \\
\hline $30-39$ years & 161 & 21,5 \\
\hline $40-49$ years & 151 & 17,9 \\
\hline $50-59$ years & 126 & 22,5 \\
\hline $60+$ years & 158 & 5,1 \\
\hline No response & 36 & $\mathbf{1 0 0 , 0}$ \\
\hline Total & $\mathbf{7 0 2}$ & \\
\hline & & \\
\hline
\end{tabular}

Table 2 provides a descriptive summary of the perceptual data - the items purported to measure satisfaction with service recovery. It reveals fairly consistent mean scores per individual item, and acceptable standard deviation scores.

Table 2: A descriptive analysis of perceptual data

\begin{tabular}{l|c|c}
\hline \multicolumn{1}{c|}{ Item name } & Mean & Standard deviation \\
\hline COMM1 & 3,64 & 1,21 \\
\hline COMM2 & 3,76 & 1,09 \\
\hline COMM3 & 3,83 & 1,11 \\
\hline COMM4 & 3,75 & 1,17 \\
\hline COMM5 & 3,85 & 1,33 \\
\hline EMP1 & 3,61 & 1,19 \\
\hline EMP2 & 3,04 & 1,39 \\
\hline EMP3 & 3,32 & 1,35 \\
\hline FEED1 & 2,59 & 1,21 \\
\hline FEED2 & 2,53 & 1,23 \\
\hline ATONE1 & 3,06 & 0,94 \\
\hline ATONE2 & 3,97 & 0,92 \\
\hline EXPLAIN1 & 3,57 & 1,23 \\
\hline EXPLAIN2 & 3,43 & 1,28 \\
\hline TANG1 & 4,06 & 0,79 \\
\hline TANG2 & 4,05 & 0,79 \\
\hline
\end{tabular}

\section{Discriminant validity}

A measure possesses discriminant validity if it does not correlate with theoretically unrelated constructs (Tull \&
Hawkins, 1993:319). The first step was thus to assess whether the data did indeed contain six 'different' dimensions as suggested by the RECOVSAT scale. For this purpose, a Maximum Likelihood Exploratory Factor Analysis was conducted, specifying a Direct Quartimin oblique rotation (Jennrich \& Sampson, 1966) of the original factor matrix. Of the 17 items contained in the RECOVSAT instrument, 16 loaded on a separate factor as expected (see Table 3). The only item that did not load as expected was the item ATONE3. ATONE 3 was therefore removed for all subsequent analyses. The Exploratory Factor Analysis thus provides considerable evidence of the discriminant validity of the RECOVSAT instrument. All factors in the 6-factor solution had Eigen values above 1,00 or close to 1,00. Also, the six factors explained $69,4 \%$ of the variance in the data space.

Table 3 thus provides sufficient evidence of discriminant validity and Proposition 1 (P1) can thus be accepted.

\section{Predictive validity}

Predictive validity refers to the extent to which a measure of an individual's future level on some variable can be predicted by his performance on a current measurement of the same or a different variable (Tull \& Hawkins, 1993: 318). In other words, as the literature contends that satisfactory service recovery (the current measurement) will lead to beneficial outcomes such as Overall Satisfaction and Loyalty (the future level), it was proposed that RECOVSAT scores would be positively related to these two variables, (Overall Satisfaction and Loyalty), as suggested by Proposition 2. To empirically test this proposition, a correlation analysis was done, using the computer programme SAS PROC CORR (SAS Institute, 1988).

Table 4 shows that the RECOVSAT scores are strongly positively correlated $(p<0,001)$ with both Overall Satisfaction and Loyalty as predicted by the literature. As a result, Proposition 2 can be accepted.

\section{Reliability}

Reliability refers to the extent to which measures or data are free from error and thus yield consistent, reproducible results. Reliability can be assessed in different ways. In thus study the internal consistency of RECOVSAT was assessed by calculating Cronbach's alpha. Cronbach alpha ranges from zero to 1 and 0,7 is generally regarded as the cut-off point to be able to claim that an instrument is reliable.

To assess the reliability of the RECOVSAT instrument, the remaining 16 items (after the removal of item ATONE 3) were then, as suggested by Churchill (1979), subjected to an internal reliability analysis using the computer programme SAS PROC CORR (SAS Institute, 1988).

Table 5 shows that the RECOVSAT instrument demonstrated a high level of reliability $(\alpha=0,899)$ not only in its entirety, but also in respect of the six individual dimensions that make up the instrument. 
Table 3: The rotated factor loadings ${ }^{(1)}$

\begin{tabular}{l|c|c|c|c|c|c}
\hline & Communication & Explanation & Tangibles & Empowerment & Atonement & Feedback \\
\hline COMM1 & $\mathbf{0 , 7 9 5}$ & 0,012 & $-0,059$ & 0,027 & $-0,043$ & 0,097 \\
\hline COMM2 & $\mathbf{0 , 7 8 4}$ & $-0,021$ & 0,028 & 0,042 & $-0,003$ & 0,042 \\
\hline COMM3 & $\mathbf{0 , 8 7 6}$ & 0,002 & 0,043 & 0,004 & 0,045 & $-0,110$ \\
\hline COMM4 & $\mathbf{0 , 8 5 5}$ & 0,047 & $-0,036$ & 0,027 & $-0,007$ & 0,008 \\
\hline COMM5 & $\mathbf{0 , 8 7 6}$ & $-0,006$ & 0,045 & $-0,072$ & 0,061 & 0,016 \\
\hline EXPLAIN1 & $-0,023$ & $\mathbf{0 , 8 7 1}$ & 0,001 & $-0,011$ & 0,018 & 0,060 \\
\hline EXPLAIN2 & 0,005 & $\mathbf{0 , 9 8 6}$ & 0,003 & 0,009 & $-0,003$ & $-0,037$ \\
\hline TANG1 & 0,016 & 0,019 & $\mathbf{0 , 8 8 3}$ & 0,007 & $-0,025$ & 0,013 \\
\hline TANG2 & $-0,028$ & $-0,018$ & $\mathbf{0 , 9 2 7}$ & $-0,004$ & 0,023 & 0,004 \\
\hline EMP1 & 0,231 & 0,125 & 0,066 & $\mathbf{0 , 4 9 5}$ & 0,024 & 0,017 \\
\hline EMP2 & $-0,078$ & $-0,059$ & $-0,019$ & $\mathbf{0 , 9 1 2}$ & $-0,011$ & 0,016 \\
\hline EMP3 & 0,038 & 0,045 & 0,010 & $\mathbf{0 , 7 5 3}$ & 0,018 & $-0,012$ \\
\hline ATONE1 & $-0,013$ & 0,034 & 0,014 & 0,001 & $\mathbf{0 , 9 1 5}$ & $-0,012$ \\
\hline ATONE2 & 0,027 & $-0,020$ & $-0,012$ & 0,005 & $\mathbf{0 , 7 7 1}$ & 0,033 \\
\hline FEED1 & 0,049 & 0,024 & 0,041 & $-0,003$ & $-0,029$ & $\mathbf{0 , 4 5 2}$ \\
\hline FEED2 & $-0,039$ & 0,002 & $-0,026$ & 0,012 & 0,071 & $\mathbf{0 , 6 1 9}$ \\
\hline Variance & & & & & & \\
explained & 3,580 & 1,757 & 1,657 & 1,653 & & 1,447 \\
\hline Eigen values & 6,33 & 1,84 & 1,63 & 1,48 & 1,13 & 0,618 \\
\hline 1) & & & & \\
\hline
\end{tabular}

1) Loadings $>$ than 0.4 were considered significant

Table 4: Correlation analysis results

\begin{tabular}{l|c|c|c}
\hline & SATIS & LOYAL & RECOVSAT \\
\hline & & & \\
\hline SATIS & 1,000 & & \\
\hline & 0,0 & & \\
\hline LOYAL & & & \\
\hline & $0,487^{* * *}$ & 1,000 & \\
\hline & 0,0001 & 0,0 & \\
\hline RECOVSAT & $0,724^{* * *}$ & $0,456^{* * *}$ & 1,000 \\
\hline & 0,0001 & 0,0001 & 0,0 \\
\hline
\end{tabular}

$* * * \mathrm{p}<0,001$

Table 5: The Internal reliability of RECOVSAT

\begin{tabular}{l|c}
\hline \multicolumn{1}{c|}{ Factor number } & $\boldsymbol{\alpha}$ \\
\hline Factor 1: Communication & 0,930 \\
\hline Factor 2: Empathy & 0,803 \\
\hline Factor 3: Feedback & 0,838 \\
\hline Factor 4: Atonement & 0,840 \\
\hline Factor 5: Explanation & 0,932 \\
\hline Factor 6: Tangibles & 0,812 \\
\hline RECOVSAT & 0,899 \\
\hline
\end{tabular}

Based on the high Cronbach Alpha values reported in Table 5 , Proposition 3 (P3) can thus be accepted. In other words, RECOVSAT is a highly reliable instrument.

\section{The empirical outcomes of satisfaction with service recovery}

The potentially positive outcomes for service firms who engineer successful and satisfactory service recovery actions, have already been alluded to. In this study, two outcomes have been suggested, namely an 'overall' assessment of satisfaction and of loyalty. Both variables were measured with instruments that were reliable $(\alpha=$ 0,779 for loyalty, and $\alpha=0,910$ for satisfaction). The instruments also demonstrated sufficient discriminant validity, as shown in Table 6 . These outcome variables (Satisfaction and Loyalty) were modelled as dependent variables in two multiple regression analyses, where the six individual service recovery dimensions were modelled as independent variables.

Table 6: Rotated factor loadings: Dependent variables

\begin{tabular}{l|c|c}
\hline & Loyalty & Satisfaction \\
\hline LOYAL1 & $\mathbf{0 , 8 2 7}$ & $-0,088$ \\
\hline LOYAL2 & $\mathbf{0 , 7 6 9}$ & 0,103 \\
\hline SATIS1 & 0,022 & $\mathbf{0 , 8 5 5}$ \\
\hline SATIS2 & $-0,007$ & $\mathbf{0 , 9 6 7}$ \\
\hline & & \\
\hline Variance explained & 1,971 & 1,687 \\
\hline Eigen values & & \\
\hline
\end{tabular}


Table 7: Multiple regression results: Satisfaction

Dependent Variable: SATISFACTION

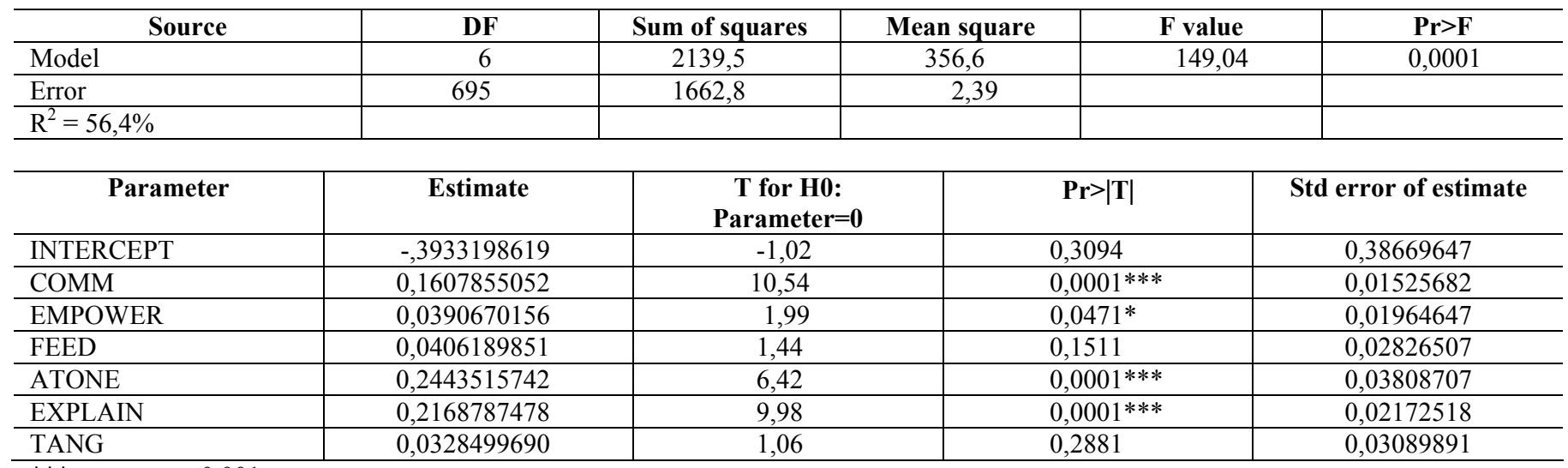

$* * *=\mathrm{p}<0,001$

$* \quad=p<0,05$

Table 7 shows that the way in which service firms communicate with customers during service delivery (COMM) exerts the most significant impact on their Overall Satisfaction (parameter estimate 10,54; $\mathrm{p}<0,001$ ), followed by the explanation (EXPLAIN) offered (estimate 9,98; p < 0,001), and Atonement (estimate 6,42; p < 0,001). The extent to which the person with whom the complaint was lodged was able or empowered to solve the problem (EMPOWER) also significantly enhanced satisfaction perceptions (estimate 1,$99 ; \mathrm{p}<0,05$ ), albeit only at the $5 \%$ level of significance. Table 7 also shows that Feedback and Tangibles were not important dimensions in influencing Satisfaction. Based on these findings, Hypothesis $1\left(\mathrm{H}^{1}\right)$ is rejected in respect of Communication, Explanation Atonement and Empowerment as they all impact positively on 'Overall Satisfaction'.

Table 8: Multiple regression results: Loyalty

Dependent Variable: LOYALTY

\begin{tabular}{l|c|c|c|c|c}
\hline \multicolumn{1}{c|}{ Source } & DF & Sum of squares & Mean square & F value & Pr $>$ F \\
\hline Model & 6 & 568,33 & 94,72 & 33,6 & 0,0001 \\
\hline Error & & & & & \\
\hline $\mathrm{R}^{2}=22,5 \%$ & 695 & 1959,16 & & & \\
\hline
\end{tabular}

\begin{tabular}{l|c|c|c|c}
\hline \multicolumn{1}{c|}{ Parameter } & Estimate & $\begin{array}{c}\text { T for H0: } \\
\text { Parameter }=0\end{array}$ & Pr $>|\mathbf{T}|$ & Std Error of Estimate \\
\hline INTERCEPT & 2,866132047 & 6,83 & 0,0001 & 0,41974457 \\
\hline COMM & 0,108318207 & 6,54 & $0,0001^{* * *}$ & 0,01656071 \\
\hline EMPOWER & 0,038266291 & 1,79 & 0,0732 & 0,02132551 \\
\hline FEED & 0,006613894 & 0,22 & 0,8294 & 0,03068068 \\
\hline ATONE & 0,113404497 & 2,74 & $0,0062^{* *}$ & 0,04134210 \\
\hline EXPLAIN & 0,033074530 & 1,40 & 0,1612 & 0,02358187 \\
\hline TANG & 0,111483959 & 3,32 & $0,0009^{* * *}$ & 0,03353961 \\
\hline
\end{tabular}

$\begin{array}{ll}* * * & =\mathrm{p}<0,001 \\ * * & =\mathrm{p}<0,01 \\ * & =\mathrm{p}<0,05\end{array}$


Table 8 reports the results when Loyalty is specified as the dependent variable. Communication is also the strongest predictor of Loyalty (estimate 6,54; $\mathrm{p}<0.001$ ), followed by Tangibles (estimate 3,32: p $<0.001$ ) and Atonement (estimate 2,74: $\mathrm{p}<0.01$ ). Table 8 , by implication, suggests that Empowerment, Feedback and Explanation are not significant predictors of Loyalty to a service firm in the case of service recovery.

Based on the empirical results reported in Table 8 , Hypothesis $2\left(\mathrm{H}^{2}\right)$ is rejected in respect of Communication, Tangibles and Atonement as they all enhance complaining customers' Loyalty to the service firm

\section{Summary of empirical findings}

The psychometric analysis reported here shows that using 'real' data collected from customers who have actually complained to a service firm, RECOVSAT demonstrates considerable evidence of construct validity. The instrument's discriminant validity, predictive validity and reliability attest to that.

The empirical results also show that Communication is the dimensions of importance to consumers when they report a service failure to a service firm. This finding is consistent with the findings of Sparks and Callan (1995) that the communication style of the service provider can positively influence customers' evaluations. The results also show that the there is a slight difference in the impact of different service recovery dimensions on a relatively short-term dimension such as Satisfaction, as opposed to a relatively long-term dimension such as Loyalty. While the appropriate communication style is important to both, it is important to note that while Tangibles do not influence the short-term measure of Satisfaction, they certainly do influence the long-term measure of Loyalty.

\section{Managerial recommendations}

It is clear that RECOVSAT is a valid and reliable instrument that can and should be used by service managers to assess customer satisfaction with their service recovery efforts. Failure to ensure that complaining customers are satisfied with the firm's service recovery efforts, can only lead to serious problems, as the service firm will be letting the customer down for a second time.

Because satisfaction with the service recovery process is primarily influenced by communication, it is of particular importance that service firms communicate clearly, ensure that all issues are clarified properly, and that staff dealing with the complaint demonstrate their understanding and are reliable. These attributes resemble a convergent communication style.

It also important that service firms atone for the customer's inconvenience by ensuring that the customer is not out-ofpocket owing to the service failure. Atonement in this context refers not only to monetary compensation, but also to the way in which the atonement is offered - preferably in a polite way.
It is equally important that service firms offer an appropriate and satisfactory explanation of why the problem occurred that led to their complaint.

To ensure that customers are satisfied with the way the service firms handled their complaints, it is also important to ensure that employees who receive complaints are empowered to solve the problem at hand. Empowered employees are ones who have been properly trained not only to handle the technical side of service delivery, but also to have the skills to handle personal interaction with (often) angry customers. Empowered employees are also given sufficient authority to ensure customer satisfaction.

Satisfaction with a transaction-specific recovery may be slightly different to long-term loyalty. For this reason service recovery's impact on loyalty was also investigated. Communication and Atonement proved to be equally important in ensuring both long-term loyalty and short-term, transactions-specific satisfaction. However, the tangible component of service recovery proved to be unimportant in influencing satisfaction, but very important in ensuring loyalty. Poorly dressed staff dealing with complaints, and dealing with complaints in an unprofessional working environment, will thus harm the long-term loyalty of complaining customers.

\section{Limitations of the study}

The empirical data for this study was collected from a single service provider and the sample must thus be regarded as a convenience sample. The results can thus not be generalised to all service providers or even to all banking institutions. In the future researchers may assess the validity and reliability of RECOVSAT in other service industries such as the airline industry and the hospitality industry. Only then will it be possible to conclude that the instrument is a generic instrument that can be used across different service industries.

\section{References}

Bearden, W. O. \& Teal, J.E. 1983. 'Selected determinants of customer satisfaction and complaint reports', Journal of Marketing Research, 20: 21 - 28.

Berry, L. L. \& Parasuraman, A. 1991. Marketing services. New York: The Free Press.

Bitner, M.J., Booms, B.H. \& Mohr, L.A. 1994. 'Critical service encounters: The employee's viewpoint', Journal of Marketing, 58:95 - 106.

Boshoff, C. 1999. 'RECOVSAT: An instrument to measure satisfaction with transaction-specific service recovery', Journal of Service Research, 1(3): 236-249.

Bowen, D.E. \& Lawler, E.E. 1992. 'The empowerment of service workers: What, Why, How and When', Sloan Management Review, 33, Spring: 31 - 39.

Churchill, G.A. 1979. 'A paradigm for developing better measures of marketing constructs', Journal of Marketing Research, 26:64 - 73. 
Conlon, D.E. \& Murray N.M. 1996. 'Customer perceptions of corporate responses to product complaints: The role of explanations', Academy of Management Journal, 39(4): 1040 - 1056.

Hart, C.W.L., Heskett, J.L. \& Sasser, W.E. Jr. 1990. 'The profitable art of service recovery', Harvard Business Review, August: 148 - 156.

Hartline, M.D. \& Ferrell, O.C. 1996. 'The management of customer-contact service employess: An empirical investigation', Journal of Marketing, 60:52-70.

Hoffman, K.D., Kelley, S.W. \& Rotalsky, H.M. 1995. 'Tracking service failures and employee recovery efforts', Journal of Services Marketing, 9:49 - 61.

Jennrich, R.I. \& Sampson, P.F. 1966. 'Rotation for simple loadings', Psychometrika, 31:313 - 323.

Johnston, R. 1994. 'Service failure and recovery: Impact, attributes and process', Advances in Service Marketing Management, 4: 1 - 23.

Keaveney, S.M. 1995. 'Customer switching behaviour in services industries: An exploratory study', Journal of Marketing, 59: 71 - 82 .

Kelley, S.W. \& Davis, M.A. 1994. 'Antecedents to customer expectations for service recovery', Journal of the Academy of Marketing Science, 22: 52 - 61 .

Perreault, W.D. \& McCarthy, E.J. 1996. Basic marketing. Chicago: Irwin.

Malholtra, N.K. 1999. Marketing research: An applied approach. Uppper Saddle River, New Jersey: Prentice-Hall.

Murray, K.B. 1991. 'A test of services marketing theory: Consumer information acquisition activities', Journal of Marketing, 55(1):10-25.

Oliver, R.L. \& Swan, J.E. 1989. 'Consumer perceptions of interpersonal equity and satisfaction in transactions: A field survey approach', Journal of Marketing, 53:21 - 35.

SAS Institute, Inc. 1988. SAS procedures, Release 6.03 Edition, Cary, N.C.

Schweikhart, S.B., Strasser, S. \& Kennedy, M.R. 1993. 'Service recovery in health services firms', Hospital and Health Services Administration, 38:3 - 21.

Smith, R.A. \& Houston, M.J. 1983. 'Script-based evaluations of satisfaction with services'. In: Berry, L.L., Shostack, G.L. \& Upah, G.D. (Eds.). Emerging perspectives on services marketing. Chicago, Illinois: American Marketing Association, Proceeding Series: 59-62.

Sparks, B.A. \& Callan, V.J. 1995. 'Dealing with service breakdowns: The influence of explanations, offers and communication style on consumer complaint behavior'. Proceedings of the World Marketing Congress. Academy of Marketing Science, Melbourne, Australia.
Tull, D.S. \& Hawkins, D.I. 1993. Marketing research: Measurement and method. $6^{\text {th }}$ Edition. New York: MacMillan Publishers.

Zeithaml, V.A., Parasuraman, A. \& Berry, L.L. 1985. 'Problems and strategies in services marketing', Journal of Marketing, 49, Spring: 33-46.

Zeithaml, V.A., Parasuraman, A. \& Berry, L.L. 1990. Delivering quality service: Balancing customer perceptions and expectations. New York: The Free Press.

Zemke, R. \& Bell, C.R. 1990. 'Service recovery', Training, 27(6):42 - 48 . 